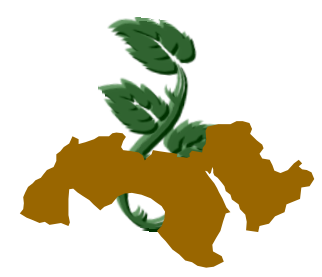

Arab Univ.

J. Agric. Sci., Ain Shams Univ., Cairo, 23(2), 497 - 513, 2015

\title{
EFFECTS OF PLANT GROWTH PROMOTING RHIZOBACTERIA ON SUMMER SQUASH GROWTH, YIELD, NUTRIENTS UPTAKE AND AVAILABILITY UNDER NITROGEN AND PHOSPHORUS FERTILIZATION LEVELS
}

\author{
Elwan $^{1 *}$, M.W.M. and S.A.M. Abd El-Azeem ${ }^{2}$ \\ 1- Department of Horticulture, Fac. of Agric., Suez Canal University, Ismailia, Egypt \\ 2- Department of Soil and Water, Fac. of Agric., Suez Canal University, Ismailia, Egypt \\ E-mail: Elwan_wasfy@yahoo.com
}

Keywords: Cucurbita pepo; PGPR; Chemical fertilizers; Yield; Nutrient uptake and availability

\section{ABSTRACT}

Two field experiments were conducted at the Experimental Research Farm, Faculty of Agriculture, Suez Canal University, Egypt during spring 2013 and 2014 using summer squash (Cucurbita pepo cv. Eskandarani) for studying the effects of PGPR strains. The objective of the first experiment was to study the efficiency of single, double and triple inoculations of Azospirillum brasilense (AC1), Bacillus subtilis (AC2) and Serratia marcescens (BM1) on summer squash fruit characters. Results showed that the double inoculations of tested PGPR strains in addition to single inoculation with Serratia marcescens produced non-significant higher fruit yield and average fruit weight compared to triple inoculation $(\mathrm{AC} 1+\mathrm{AC} 2+\mathrm{BM} 1)$ and single inoculation with Azospirillum brasilense. However, non-inoculated control plants and plants inoculated with Bacillus subtilis showed lower fruit yield and average fruit weight. From the previous results, it concluded that the double inoculation were better than single and triple inoculations. However, the aim of the second experiment was to evaluate the efficiency of PGPR under $N$ and $P$ fertilization levels on plant growth, yield and nutrients uptake of summer squash as well as soil nutrient availability (available $\mathrm{N}$ and $\mathrm{P}$ ). As per main effects, generally, plant growth, fruit yield, nutrients uptake and availability enhanced significantly by increasing $\mathrm{N}$ and $\mathrm{P}$ levels, except half dose of $\mathrm{P}$ which gave statistically equivalent values of plant fresh and dry weight as well as nitrogen uptake in shoots and fruits in addition to $P$ in shoots compared to full dose. Also, main effect of PGPR showed that the inoculated plants gave significantly higher plant growth, fruit yield, nutrient uptake and availability compared to un-inoculated control plants. Inoculated plants with PGPR strains under full dose of $\mathrm{N}$ and $\mathrm{P}$ gave mostly highest plant growth, fruit yield, nutrients uptake and availability. This effect was at significant level in terms of fruit yield, soil nutrient availability and some nutrients uptake such as $\mathrm{K}$ in the shoots and $\mathrm{N}$ the fruits. Furthermore, PGPR significantly reduced $P$ fertilizer application without any reduction in squash yield, especially under no and half dose of $N$ fertilizer. Results revealed that the efficiency of PGPR strains increased by $P$ increasing and decreased by $\mathrm{N}$ increasing.

\section{INTRODUCTION}

Squash (Cucurbita pepo L.) is one of the most popular vegetable crops grown in Egypt and other countries of the Mediterranean region. Approximately, 1.79 million ha are cultivated annually with squash, pumpkin and gourd worldwide with 24.62 million tons with an average of 13.76 tons/ha. The cultivated area in Egypt decreased from 35.520 thousand ha in 2011 to 30.9 thousand in 2012 (FAO, 2012). Sustainability of agricultural system of use of huge amounts of chemical fertilizers are contradictory. Unfortunately, these continued uses of chemical fertilizers often results in unexpected 
environmental impacts, including reduction in water quality eutrophication of marine ecosystem, the development of photochemical smog and increasing concentration of the greenhouse gas (Vitousek et al 1997). Therefore, integrated nutrient management (INM) systems are an urgent need to find alternative strategies that can partially eliminate the negative effects of mineral fertilizers and enhance nutrient-use efficiency (Adesemoye and Kloepper, 2009). Use of microbial inoculants or plant growth-promoting rhizobateria (PGPR) are promising constitute of such management system. PGPR are free-living soil bacteria that aggressively colonize the rhizosphere of plant roots, and enhance the growth, and yield of plants when applied to seed or plants (Kloepper and Schroth, 1978). PGPR can promote plant growth through direct or indirect mechanisms, but our knowledge about the mechanisms that are involved is very limited. PGPR can increase nutrient availability through asymbiotic nitrogen fixation, iron sequesterization, solubilization of insoluble mineral phosphate and other nutrients, production of 1-aminocyclopropane 1-carboxylate (ACC) deaminase, and the synthesis of growth-promoting substances, including phytohormones (Hontzeas et al 2005; Shrivastava and Kumar 2011; Sharma and Rai, 2015; Mehta et al 2015; Kumar et al 2015; Goswami et al 2015). The indirect promotion occurs through the induction of resistance in plant hosts against pathogens (Yang et al 2009). PGPR have been reported to facilitate the growth and yield of vegetable crops such as squash (Abou-Aly et al 2006), bitter gourd (Kumar et al 2012), tomato and pepper (Lucas Garcia et al 2004; Tariq et al 2014), strawberry (Ipek et al 2014), and broccoli (Tanwar et al 2014) under pot and field conditions. Additionally, PGPR have been studied extensively for induction of resistance against pathogenic microorganisms in vegetable crops such as on squash (Zhang et al 2010; Shehata, Sawsan and ElBorollosy, 2008).

The application of PGPR for enhancing plant nutrition and partially compensating the need of mineral fertilizers is becoming a common strategy for INM system (Shaharoona et al 2008). However, there is an excessive deal of unpredictable information on the effectiveness of PGPR on plant growth and yield in soil treated with different rates of fertilizers (Tailor and Joshi, 2014; Ahemad and Kibret, 2014). It is well reported that the PGPR are more effective in improving plant growth and yield under limited nutrient supply (Adesemoye et al 2009); however, several of investiga- tors studied the response of the individual nutrient such as nitrogen. In this regard, nitrogen-fixing bacteria were used as microbial inoculants, while the growth-promoting behavior of non- $\mathrm{N}_{2}$ fixing bacteria has not been investigated comprehensively. Specifically, there is a lack of research on the effectiveness of PGPR for improving growth and yield of vegetable crops under application of different rates of $N$ and $P$ fertilizers. Squash responses to mineral fertilizers ( $\mathrm{N}$ or $\mathrm{P}$ ) alone are well examined (Mohammad, 2004; Mohammad et al 2004), however, to our knowledge the responses of both fertilizers in combination with PGPR under arid and semi-arid conditions are not studied. Therefore, the objective of the first field experiment was to evaluate the effects of single, double and triple inoculation with PGPR strains on squash fruit yield characters. However, the objective of the second field experiment was to examine the effectiveness of the interaction among $\mathrm{N}$ and/or $\mathrm{P}$ fertilizers with PGPR mixture on plant growth, fruit yield characters, aerial and fruits mineral uptake and the availability of soil nutrients.

\section{MATERIALS AND METHODS}

\section{Plant materials and growth conditions}

Two field experiments were conducted in consecutive spring growing season of 2013 and 2014 at the Experimental Research Farm, Faculty of Agriculture, Suez Canal University, Ismailia, Egypt using summer squash (Cucurbita pepo cv. Eskandarani). Randomized sandy soil samples were collected at $0-30 \mathrm{~cm}$ depth, before plantation and homogenized together to determine some physicochemical characteristics of air-dried, crushed, and sieved (<2 mm) soil according to Gee and Bauder (1986) and Sparks et al (1996) (Table 1).

The soil of the experimental site was cleared, ploughed and harrowed, and then the drip irrigation lines were placed. During the preparation of soil for cultivation, the organic matter (cattle manure) at the rate of $20 \mathrm{~m}^{3} \mathrm{fad}^{-1}$ and ordinary superphosphate $\left(15.5 \% \quad \mathrm{P}_{2} \mathrm{O}_{5}\right)$ were thoroughly mixed with the soil. Summer squash cv. Eskandarani was direct-seeded $30 \mathrm{~cm}$ apart and $100 \mathrm{~cm}$ between rows. After 3 weeks from seeding, ammonium nitrate as nitrogen source was applied twice a week. The experimental unit represented by a single line of $12 \mathrm{~m}$ length and $1 \mathrm{~m}$ width using drip irrigation system. Squash fruits were harvested every day for 4 weeks, beginning 40 days from seeding. Fruits were harvested when reached marketable size (over $12 \mathrm{~cm}$ ). 
Table 1. Properties of the soil used in the present study

\begin{tabular}{|c|c|}
\hline Properties & Value \\
\hline \multicolumn{2}{|l|}{ Particle size distribution (\%) } \\
\hline Sand & 94.80 \\
\hline Silt & 2.08 \\
\hline Clay & 3.12 \\
\hline Textural class & Sand \\
\hline $\mathrm{CaCO}_{3}\left(\mathrm{~g} \mathrm{~kg}^{-1}\right)$ & 6.2 \\
\hline $\mathrm{pH}^{\dagger}$ & 7.83 \\
\hline $\mathrm{EC}_{\mathrm{e}}\left(\mathrm{dS} \mathrm{m}^{-1}\right)^{\ddagger}$ & 1.50 \\
\hline \multicolumn{2}{|l|}{ Soluble cations $\left(\mathrm{meq} \mathrm{l}^{-1}\right)^{\ddagger}$} \\
\hline $\mathrm{Ca} 2+$ & 7.31 \\
\hline $\mathrm{Mg} 2+$ & 1.46 \\
\hline $\mathrm{Na}+$ & 5.04 \\
\hline $\mathrm{K}+$ & 1.37 \\
\hline \multicolumn{2}{|l|}{$\underline{\text { Soluble anions }\left(\mathrm{meq}^{-1}\right)^{\ddagger}}$} \\
\hline HCO3- & 3.41 \\
\hline $\mathrm{Cl}-$ & 8.77 \\
\hline SO42- & 2.83 \\
\hline Organic C (g kg-1) & 2.50 \\
\hline Available $\mathrm{N}$ (mg kg-1) & 14.35 \\
\hline Olsen-P (mg Kg-1) & 8.89 \\
\hline
\end{tabular}

${ }^{\dagger}$ In soil-water suspension (1:2.5), ${ }^{\ddagger}$ In soil saturated extracts.

\section{Rhizobacterial strains and plant inoculation}

Three strains of PGPR, Azospirillum brasilense AC1, Bacillus subtilis AC2 and Serratia marcescens BM1, were used in this study. The strains were isolated from the rhizospheric soils of clover and maize plants grown in El Abtal Village, Sarabium and Bahr El-Baker, Port-Said, respectively, Ismailia, Egypt. The rhizobacterial strains were selected based on the prior knowledge of their ability to produce siderophores and indole acetic acid (IAA), and solubilize inorganic phosphate as shown in Table (2) (Abd El-Azeem et al 2007).

The PGPR strains were grown as static batch cultures in a 500-ml Erlenmeyer flask containing $200 \mathrm{ml}$ sterile tryptic soy broth (TSB) medium (Starr et al 1981) at $28{ }^{\circ} \mathrm{C}$ for 4 days. The cultures were then diluted 10 times with distilled water resulting $10^{8}$ colony-forming units (cfu) $\mathrm{mL}^{-1}$. After 3 weeks from seeding, the bacterial suspensions were applied at the rate of $100 \mathrm{ml} \mathrm{plant}^{-1}$. The bac- terial suspension was repeated once after 10 days. Non-inoculated (controls) received fresh TSB medium diluted 10 times. For double and triple inoculation, the mixtures of PGPR strains were prepared by combining equal proportions of each strain prior to application to the plant. Additionally, the individual strains in the mixture are compatible with each other and not inhibit the other strains.

\section{First experiment}

One-way experiment was conducted to investigate the effect of inoculation with three PGPR strains separately or in double and triple combinations (Table 2) on summer squash fruit yield characters. Squash seeds were cultivated from March, 15 to May, 21, 2013. Treatments were arranged in completely randomized block design with four replications. Fruit number, average fruit weight ( $g /$ fruit), fruit yield ( $g /$ plant) were recorded and fruit yield (t/fad.) was calculated.

\section{Second experiment}

From the first experiment, the maximum fruit yield was observed when plant inoculated with PGPR mixtures Bacillus subtilis AC2 plus Sarratia marcescens BM1 and Azospirillum brasilense AC1 plus Sarratia marcescens BM1. However, the selection of Azospirillum brasilense + Serratia marcescens mixture for this experiment based on their highly phosphorus solubilization and high IAA production for first and second strain (Table 2), respectively. This experiment was completed to investigate the effect of interaction among nitrogen levels, phosphorus levels and inoculation of PGPR mixture strains on plant growth, fruit yield characters, macro-elements (NPK) in aerial parts and fruits as well as nitrogen and phosphorus availability in cultivated soil at the end of the experiment. Squash seeds were cultivated from April 6 to June 15, 2014. The experiments were laid-out in a splitsplit plot in randomized complete block design with three replicates. This experiment included eighteen treatments which were in a combination among three nitrogen levels $(0.0,45$ and $90 \mathrm{~kg} \mathrm{~N} / \mathrm{fed}$.), three phosphorus levels $(0.0,22.5$ and $45 \mathrm{~kg} / \mathrm{fad}$.), which corresponding to 0 , half and full doses, and with or without of PGPR strain mixtures. Nitrogen was subjected to main plot, phosphorus was occupied sub-plot and inoculation with PGPR strains occupied sub-sub plot. 
Table 2. Plant growth promoting traits and plant hosts of the rhizobacterial strains used in the present study

\begin{tabular}{|c|c|c|c|c|c|c|}
\hline \multirow{3}{*}{ Strains } & \multirow{3}{*}{ Species } & \multirow{3}{*}{$\begin{array}{l}\text { Plant } \\
\text { Host }\end{array}$} & \multicolumn{3}{|c|}{ Plant growth promoting traits } & \multirow{3}{*}{$\begin{array}{c}\text { Siderophore } \\
\text { production }\end{array}$} \\
\hline & & & \multicolumn{2}{|c|}{$\mathrm{IAA}^{\dagger}$ production } & \multirow{2}{*}{$\mathbf{P}^{\ddagger}$ solubilization } & \\
\hline & & & With I-TRP & Without I-TRP & & \\
\hline$A C 1$ & Azospirillum brasilense & Clover & 17.82 & 7.22 & 362.0 & - \\
\hline AC2 & Bacillus subtilis & Clover & 4.65 & 2.70 & 191.21 & + \\
\hline BM1 & Serratia marcescens & Maize & 25.40 & 9.79 & 102.79 & - \\
\hline
\end{tabular}

${ }^{\dagger}$ IAA: Indole acetic acid production ( $\left.\mathrm{mg} \mathrm{l}^{-1}\right)$ in liquid culture with and without 1 -tryptophan (I-TRP).

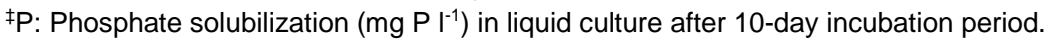

At the end of the experiment, three plants were packed out from each replicate and divided into shoots and fruits, then weighted, dried at $70^{\circ} \mathrm{C}$ for $72 \mathrm{~h}$ and dry weights were recorded. The plant materials were ground and total $\mathrm{N}$ in shoots and fruits were determined by the Kjeldahl method (Bremner, 1996). Phosphorus and potassium contents were determined after wet digestion using a nitric $\left(\mathrm{HNO}_{3}\right)$-sulfuric $\left(\mathrm{H}_{2} \mathrm{SO}_{4}\right)$-perchloric $\left(\mathrm{HClO}_{4}\right)$ acid mixture $(4: 1: 8 \mathrm{v} / \mathrm{v})$. The $P$ was measured spectrophotometrically using the molybdenum-blue method (Jackson, 1973) and the potassium was measured using the flame photometer (Sparks et al 1996).

Soil samples were collected at the end of the experiment from each replicate for the availability of $\mathrm{N}$ and $\mathrm{P}$ analysis. Briefly, available inorganic $\mathrm{N}$ was extracted using $2.0 \mathrm{M}$ potassium chloride and determined according to the Kjeldahl method (Bremner, 1996). The available inorganic $P$ was determined by the spectrophotometer in $0.5 \mathrm{M}$ $\mathrm{NaHCO}_{3}$-soil extract according to the Olsen method (Kuo, 1996).

\section{Statistical analysis}

Data were statistically analyzed by analysis of variance (ANOVA) using the Statistica 6 software (StatSoft, 2001), and the mean values were compared using Duncan's multiple-range test. Values of $P \leq 0.001,0.01$ and 0.05 were considered to indicate significance.

\section{RESULTS AND DISCUSSION}

First experiment: PGPR and fruit yield characters

Effectiveness of PGPR strains Azospirillum brasilense AC1, Bacillus subtilis AC2 and Sarratia marcescens BM1 for improving fruit yield of squash is evident from the data given in Table (3). Results generally revealed that individual, double and triple inoculation of tested PGPR strains increased significantly fruit yield of summer squash compared to un-inoculated plants, except the individual inoculation with Bacillus subtilis AC2, which was not increased significantly the fruit yield compared to control. The results also indicated that the double inoculation of Bacillus subtilis with Azospirillum brasilense or Sarratia marcescens increased significantly the fruit yield compared to single inoculation. However, the double inoculation of Azospirillum brasilense or Sarratia marcescens nonsignificantly increased the fruit yield compared to their single inoculations. The triple inoculation showed less fruit yield than all double inoculations and single inoculation with Sarratia marcescens. The indicated results showed that the highest fruit yield ( $\mathrm{t} / \mathrm{fad}$.) and average fruit weight ( $\mathrm{g} /$ fruit) were observed in squash plants inoculated with the double mixtures of Sarratia marcescens with Azospirillum brasilense or Bacillus subtilis, followed by individual inoculation of Sarratia marcescens. The increasing percentage of fruit yield was $51.6 \%$ and $48.1 \%$ for double inoculation of both strains, 
Table 3. Effect of Plant growth promoting rhizobacteria (PGPR) separately or in combinations on fruit yield characters of summer squash cv. Esqndrani

\begin{tabular}{|l|ccc|}
\hline \multicolumn{1}{|c|}{ PGPR Strain } & Fruit No. & Fruit weight (g/fruit) & $\begin{array}{c}\text { Fruit yield } \\
\text { (t/fad.) }\end{array}$ \\
\hline Control & $5.42 \mathrm{ab}$ & $77.56 \mathrm{~d}$ & $5.85 \mathrm{c}$ \\
Bacillus subtilis AC2 & $6.28 \mathrm{a}$ & $73.19 \mathrm{~d}$ & $6.47 \mathrm{bc}$ \\
Azospirillum brasilense AC1 & $5.92 \mathrm{ab}$ & $92.16 \mathrm{c}$ & $7.63 \mathrm{ab}$ \\
Sarratia marcescens BM1 & $4.86 \mathrm{~b}$ & $119.03 \mathrm{a}$ & $8.41 \mathrm{a}$ \\
B. subtilis + A. brasilense & $5.28 \mathrm{ab}$ & $102.63 \mathrm{~b}$ & $7.86 \mathrm{a}$ \\
B. subtilis + S. marcescens & $5.35 \mathrm{ab}$ & $117.74 \mathrm{a}$ & $8.87 \mathrm{a}$ \\
A. brasilense + S. marcescens & $5.32 \mathrm{ab}$ & $118.25 \mathrm{a}$ & $8.67 \mathrm{a}$ \\
B. subtilis + A. brasilense + S. marcescens & $5.18 \mathrm{ab}$ & $105.98 \mathrm{abc}$ & $7.70 \mathrm{ab}$ \\
\hline
\end{tabular}

Notes. Values are the means of three replicates. Values followed by the same letter within a column are not significantly different at the $0.05 \%$ level of probability according to Duncan's multiple-range test

respectively and $43.7 \%$ for individual inoculation of Sarratia marcescens compared to un-inoculated plants. Results revealed also, the number of fruits/plant did not significantly affected by PGPR treatments compared to control plants.

The present study indicated that inoculation with PGPR strains had a positive effect on summer squash yield character under field conditions. The PGPR strains used in this study have the ability to produce IAA and siderophores and to enhance the solubilization of insoluble inorganic phosphate as shown in Table (2) (Abd El-Azeem et al 2007). In this experiment, the inoculation with PGPR strains increased the yield of summer squash regardless the type of inoculation method. These increases were likely due to the positive effects of the tested PGPR strains on plant growth by the production of phytohormones such as IAA, cytokinins and gibberellins (Persello-Cartieaux et al 2003; Somers et al 2005). Additionally, the plant-growth promotion by some PGPRs has been observed to be correlated with the solubilization and increased uptake of iron and phosphate (Guang-Can et al 2008). The positive effects of the tested PGPR strains were also attributed to ability of these strains to interact with plants roots and can protect them against pathogens (Zhang et al 2010; Shehata, Sawsan and El-Borollosy, 2008). In this regard, Mena-Violante and Olalde-Portugal (2007) concluded that the inoculation of tomato seedlings with Bacillus subtilis led to an increasing yield per plant and marketable grade yield when compared to the control treatment. The results showed that the double inoculation (Bacillus subtilis with Azospirillum brasilense or Sarratia mar- cescens) significantly increased the fruit yield when compared to single inoculation. This may be due to the combination of PGPR strains with different metabolic activity (production of IAA and inorganic phosphate solubilization, Table 2) can partially exceed the effect of single inoculation or can produce appositive effect where single inoculation are ineffective (Felici et al 2008). However, the double inoculation was not consistently a significant increase of squash yield. Although, we measured the absence antagonism between the selected PGPR strains in vitro does not alleviate the possibility of the tested PGPR neutralizing each other in the rhizosphere. The inoculated microorganisms compete for space and/or sources of nutrients and carbon within the rhizosphere, and subsequently the survival rates of either or both PGPR decline (Ogut et al 2005). The maximum fruit yield was observed when squash was inoculated with mixtures of Sarratia marcescens with Bacillus subtilis or Azospirillum brasilense, followed by individual inoculation of Sarratia marcescens. These findings suggest that Sarratia marcescens could increase plant growth by the production of IAA and Azospirillum brasilense could increase squash mineral nutrition (Table 2).

Second experiment: Interaction effects of PGPR strains mixture and chemical fertilizers (nitrogen and phosphorus)

\section{Plant growth and yield}

Mostly main effects of nitrogen and phosphorus rates as well as inoculation with mixture of PGPR 
strains were significantly influenced the plant growth and fruit yield $(P<0.001)$ of summer squash (Tables 4 and 5). Plant growth, and fruit yield characters were significantly increased by increasing nitrogen rate from 0.0 to $90 \mathrm{~kg} \mathrm{~N}$ fad. ${ }^{-1}$. The percentage of increasing was $201.24 \%, 146.08 \%$, $96.7 \%, 39.85 \%, 173.26 \%$ for foliage fresh weight, foliage dry weight, fruit number/plant, average fruit weight and fruit yield, respectively. The improvement of plant growth and fruit yield of summer squash by increasing nitrogen rate could be attributed to the increase in nitrogen uptake and also to its associated role in chlorophyll synthesis and hence the process of photosynthesis as reported by Jasso-Chaverria et al (2005). The results are supported by the results of Elwan and ElShatourty (2012) on the same cultivar where the plant growth and fruit yield increased by increasing nitrogen rate from 0.0 to $90 \mathrm{~kg} / \mathrm{fad}$.

Foliage fresh and dry weight as well as fruit number per plant were increased by increasing phosphorus rate from 0.0 to $22.5 \mathrm{~kg} \mathrm{P}_{2} \mathrm{O}_{5}$ fad. $^{-1}$, then a non-significant changes was observed by increasing phosphorus rate from $22.5 \mathrm{~kg} \mathrm{P}_{2} \mathrm{O}_{5}$ fad. ${ }^{1}$ to $45 \mathrm{~kg} \mathrm{P}_{2} \mathrm{O}_{5}$ fad. $^{-1}$. Also, a gradual increase in fruit yield by increasing phosphorus rate from 0.0 to $45 \mathrm{~kg} \mathrm{P} 2 \mathrm{O}_{5}$ fad. $^{-1}$, however, average fruit weight significantly increased only by increasing phosphorus rate from $22.5 \mathrm{~kg} \mathrm{P}_{2} \mathrm{O}_{5}$ fad. $^{-1}$ to $45 \mathrm{~kg} \mathrm{P}_{2} \mathrm{O}_{5}$ fad. ${ }^{1}$ and non-significant difference was found between 0.0 and $22.5 \mathrm{~kg} \mathrm{P}_{2} \mathrm{O}_{5} \mathrm{fad}^{-1}$ (Table 5). This stimulatory effect of $P$ on summer squash yield may be attributed to its vital role as ATP in enhancing metabolic activities of plant. Such activities may include photosynthesis, starch synthesis, glycolysis and protein synthesis (Shalaby and Ahmed, 1993).

Regarding the inoculation with mixture of PGPR strains, results revealed that the inoculated plants showed a significant increase in plant growth and fruit yield characters compared to uninoculated plants (Table 5). The positive response of squash yield due to inoculation with the PGPR mixture could be partially explained on the basis that these mixture include strains possess a number of plant growth promoting traits including solubilization of insoluble phosphates and production of indole acetic acid (IAA) (Table 2).

With respect to effectiveness of interaction among PGPR, nitrogen and phosphorus levels for improving plant growth and fruit yield of summer squash is apparent from the data presented in Table (6). The results revealed that the highest foliage fresh and dry weight were noticed at high ni- trogen rate $\left(90 \mathrm{~kg} \mathrm{~N}\right.$ fad. $^{-1}$ ) when combined with any treatment from other two tested factors (phosphorus and PGPR), except the treatment without phosphorus and un-inoculated with PGPR which showed less foliage fresh and dry weight. Also, under half dose of nitrogen and full dose of phosphorus, the inoculated plants with PGPR gave the highest shoot dry weight. At zero nitrogen and phosphorus levels, the inoculated plants produced significant higher shoot fresh and dry weight compared to un-inoculated ones. The indicated results at half dose of nitrogen, the inoculated plants gave significant higher shoot fresh weight under each phosphorus level compared to un-inoculated plants.

The results presented here showed that PGPR can improve the nutrient use efficiency of fertilizers which led to increase plant growth and fruit yield. Previous reports have suggested positive impacts of PGPR strains on $\mathrm{N}$ uptake involving non-legume biological fixation (Adesemoye et al 2009; Adesemoye and Kloepper, 2009; Kim et al 2010; Yildirim et al 2011; Tahir et al 2013; Saber et al 2012; Yasin et al 2012; Abdel-Aziez, Samah et al 2014). In the same direction, inoculation with PGPR strains resulted in $P$ solubilization or enhanced plant uptake of fixed soil $P$ and applied phosphate resulting in higher crop yield (Malboobi et al 2009; Ekin 2010; Zabihi et al 2011; Zafar et al 2011; Yousefi et al 2011; Haque and Khan, 2012; Dinesh et al 2013; Tanwar et al 2014; Moinuddin et al 2014). Additionally, the inoculation with PGPR can alleviate salt stress, and subsequently increased the yield of vegetables crops. In this respect, the same authors concluded that the inoculation of the eggplant seedlings with PGPR could alleviate the negative effects of salt stress (Abd El-Azeem et al 2012).

The squash plants received higher nitrogen and phosphorus levels (90 and $45 \mathrm{~kg} \mathrm{fad}^{-1}$, respectively) and inoculated with mixture of PGPR strains gave the significant highest fruit number per plant and fruit yield per fadden in addition to nonsignificant highest average fruit weight. The presented data showed that the plants received half dose of phosphorus and inoculated with mixture of PGPR strains gave statistically equal values of fruit yield of squash compared to plants received full dose of phosphorus and un-inoculated with PGPR under each nitrogen level.

It is difficult to compromise on actual potential of crop productivity by increasing number of population worldwide; therefore, all the efforts should be focused on maximizing the crop production along 
Table 4. Results of analysis of variance (ANOVA) of nitrogen $(N)$, phosphorus $(P)$ and plant growth promoting rhizobacteria (PGPR) effects and their interaction for the variables listed.

\begin{tabular}{|c|c|c|c|c|c|c|c|c|c|c|c|c|c|c|}
\hline \multirow{2}{*}{ S.O.V. } & \multirow{2}{*}{ df } & \multirow{2}{*}{$\begin{array}{c}\text { Shoot } \\
\text { FW }\end{array}$} & \multirow{2}{*}{$\begin{array}{c}\text { Shoot } \\
\text { DW }\end{array}$} & \multirow{2}{*}{$\begin{array}{l}\text { Fruit } \\
\text { No. }\end{array}$} & \multirow{2}{*}{$\begin{array}{c}\text { Average } \\
\text { Fruit } \\
\text { weight }\end{array}$} & \multirow{2}{*}{$\begin{array}{l}\text { Fruit } \\
\text { yield }\end{array}$} & \multicolumn{3}{|c|}{ Shoot } & \multicolumn{3}{|c|}{ Fruits } & \multicolumn{2}{|c|}{ Soil } \\
\hline & & & & & & & $\mathbf{N}$ & $\mathbf{P}$ & $\mathrm{K}$ & $N$ & $\mathbf{P}$ & $\mathrm{K}$ & $\mathbf{N}$ & $\mathbf{P}$ \\
\hline $\begin{array}{l}\text { Nitrogen } \\
(\mathrm{N})\end{array}$ & 2 & $* * *$ & $* * *$ & $* * *$ & $* * *$ & $* * *$ & $* * *$ & $\star * *$ & $\star * *$ & $\star * *$ & $* * *$ & $* * *$ & $* * *$ & $* * *$ \\
\hline $\begin{array}{l}\text { Phosphorus } \\
\text { (P) }\end{array}$ & 2 & $* * *$ & $* * *$ & $* * *$ & *** & $* * *$ & $* * *$ & $\star * *$ & $\star * *$ & $* * *$ & $* * *$ & $* * *$ & $* * *$ & $* * *$ \\
\hline PGPR & 1 & $* * \star$ & $\star \star \star *$ & * & $* \star *$ & $* * *$ & $* * *$ & $\star \star \star *$ & 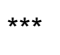 & $* \star *$ & $* * *$ & $* \star *$ & $* \star *$ & $* \star \star$ \\
\hline$N^{*} P$ & 4 & ns & ** & * & $* * *$ & $* *$ & $* *$ & $* * *$ & $\star * *$ & $* *$ & $* * *$ & $* * *$ & $* * *$ & $* * *$ \\
\hline$N^{*} P G P R$ & 2 & $* * *$ & ** & ns & ns & ns & $* * *$ & $* * *$ & $\star * *$ & ns & $* *$ & $* * *$ & $* * *$ & $* * *$ \\
\hline$P * P G P R$ & 2 & ns & ns & * & $\star * *$ & * & $* * *$ & ns & $\star \star \star *$ & * & $\star * *$ & $* * *$ & $* * *$ & $* * *$ \\
\hline $\mathrm{N}^{*} \mathrm{P}^{*} \mathrm{PGPR}$ & 4 & ns & $\mathrm{ns}$ & ** & $* * *$ & ** & $* * *$ & $* * *$ & $\star * *$ & ns & $* *$ & $* * *$ & $* * *$ & $* * *$ \\
\hline
\end{tabular}

NS, non-significant. ${ }^{*}$ Significant at the $5 \%$ level. ${ }^{* *}$ Significant at the $1 \%$ level. ${ }^{* *}$ Significant at the $0.1 \%$ level

Table 5. Effects of nitrogen rate, phosphorus rate and mixture of PGPR on plant growth and fruit yield characters of summer squash cv. Esqndrani

\begin{tabular}{|c|c|c|c|c|c|c|}
\hline Main effect & Levels & $\begin{array}{c}\text { Shoot fresh } \\
\text { weight (g/plant) }\end{array}$ & $\begin{array}{c}\text { Shoot dry } \\
\text { weight } \\
\text { (g/plant) }\end{array}$ & $\begin{array}{c}\text { Fruit } \\
\text { No./plant }\end{array}$ & $\begin{array}{l}\text { Fruit weight } \\
\text { (g/fruit) }\end{array}$ & $\begin{array}{l}\text { Fruit yield } \\
\text { (t/fad.) }\end{array}$ \\
\hline \multirow{3}{*}{$\begin{array}{c}\text { Nitrogen } \\
\text { (kg N fad.-1) }\end{array}$} & 0.0 & 592.92 c & $73.28 \mathrm{c}$ & $3.33 \mathrm{c}$ & $57.47 \mathrm{c}$ & $2.71 \mathrm{c}$ \\
\hline & 45 & $1380.8 \mathrm{~b}$ & $140.54 b$ & $5.97 \mathrm{~b}$ & $74.19 \mathrm{~b}$ & $6.22 \mathrm{~b}$ \\
\hline & 90 & $1786.1 \mathrm{a}$ & $180.33 \mathrm{a}$ & $6.55 \mathrm{a}$ & $80.37 \mathrm{a}$ & $7.40 \mathrm{a}$ \\
\hline \multirow{3}{*}{ 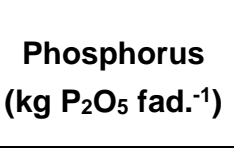 } & 0.0 & $1184.7 b$ & $122.86 \mathrm{~b}$ & $4.85 b$ & $69.77 \mathrm{~b}$ & $5.00 \mathrm{c}$ \\
\hline & 22.5 & $1293.8 \mathrm{a}$ & $139.76 \mathrm{a}$ & $5.47 \mathrm{a}$ & $67.93 b$ & $5.36 \mathrm{~b}$ \\
\hline & 45.0 & $1314.2 \mathrm{a}$ & $139.71 \mathrm{a}$ & $5.53 \mathrm{a}$ & $74.33 \mathrm{a}$ & $5.95 \mathrm{a}$ \\
\hline \multirow{2}{*}{$\begin{array}{l}\text { PGPR strain } \\
\text { mixture }\end{array}$} & Uninoculated & $1151.8 b$ & $123.79 b$ & $5.19 b$ & $68.33 \mathrm{~b}$ & $5.16 \mathrm{~b}$ \\
\hline & Inoculated & $1369.9 \mathrm{a}$ & $143.12 \mathrm{a}$ & $5.38 \mathrm{a}$ & $73.02 \mathrm{a}$ & $5.72 \mathrm{a}$ \\
\hline
\end{tabular}

Notes. Values are the means of three replicates. Values followed by the same letter within a column are not significantly different at the $0.05 \%$ level of probability according to Duncan's multiple-range test.

with the judicial use of chemical fertilizers. This situation demands the selection of the PGPR which could enhance crop yield over and above that obtainable by optimum fertilization. Hence, inoculation with mixture of PGPR strains (Azospirillum brasilense and Serratia marcescens) that caused approximately $24 \%$ increases in yield over respective un-inoculated controls in the presence of full doses of $\mathrm{N}$ and $\mathrm{P}$ could be a viable supplementary strategy for further increasing squash yield. Moreover, in some cases, the results of this study suggest that excessive use of chemical fertilizer could be avoided by using mixture of PGPR strains. This is supported by the data that the yield of un-inoculated plants at half dose of $\mathrm{N}$ and $\mathrm{P}$ was statistically equals with that obtained with inoculation plus half dose of recommended $\mathrm{N}$ fertilizer in the absence of $P$ fertilizer.

The indicated results revealed that the inoculation with mixture of PGPR strains increased fruit yield, however, in most cases, the efficiency of inoculation decreased with increasing nitrogen levels under each phosphorus level (Table 6). Contradictory results regarding to phosphorus, the efficacy of inoculation increased with increasing phosphorus levels under each nitrogen level, es- 
pecially under low $(0.0 \mathrm{~kg} / \mathrm{fad}$.) and high nitrogen levels (90 kg/fad.). The efficiency of PGPR strains increased by increasing of $P$, could be explained by that these mixture include strains possess a number of plant growth promoting traits including solubilization of insoluble phosphates (Table 2). The phosphate solubilizing microorganisms translate insoluble phosphates into soluble forms through the process of acidification, chelation, and exchange reactions as reported by Rodriguez et al. (2004). The efficiency of PGPR decreased by nitrogen increased may be due to the PGPR mixture containing Azospirillum brasilense that have ability to non-symbiotic $\mathrm{N}_{2}$ fixation. The addition of nitrogen fertilizers can inhibit the rate of $\mathrm{N}_{2}$ fixation by Azospirillum brasilense (Steenhoudt and Vanderleyden, 2000). The tested PGPR strains in this study also showed a responsible for IAA production, which play an important role in division, expansion and differentiation of plant cells and tissues and stimulates root elongation as reported by Tsavkelova et al (2006) which led to higher plant growth and fruit yield such as in the present study (Table 6).

\section{Plant nutrient uptake}

Main effects of nitrogen and phosphorus rates in addition to mixture of PGPR strains on nutrient $(\mathrm{N}, \mathrm{P}$ and $\mathrm{K}$ ) uptake in shoots and fruits of summer squash are presented in Table (7). The presented results in ANOVA Table indicated that the nutrient uptake mostly significantly influenced by application of nitrogen, phosphorus, PGPR strains and their double and triple interactions (Table 4). As per the main effects of $\mathrm{N}$ and $\mathrm{P}$, progressive application of $\mathrm{N}$ and $\mathrm{P}$ enhanced the uptake of $\mathrm{N}, \mathrm{P}$ and $\mathrm{K}$ in fruits as well as in shoots, except $\mathrm{N}$ uptake in shoots and fruits as well as $P$ uptake in shoots which were statistically un-changed between half and full dose of phosphorus fertilizer. These results confirmed by the results of $\mathbf{L i}$ et al (2003) who found that the nitrogen and phosphorus uptake increased by increasing nitrogen fertilizer in maize, wheat and faba bean. Considering the main effects of mixture of PGPR strains, the maximal values of the $\mathrm{N}, \mathrm{P}$ and $\mathrm{K}$ uptake in shoots and fruits were shown by application of mixture of PGPR strains compared to the control (un-inoculated), which always gave the minimum values (Table 7). The favorable effects of increasing $N$ and $P$ levels as well as inoculation with PGPR strains on mineral uptake in the shoots and fruits may due to increasing dry weight of shoots and higher fruit yield (Ta- ble 5), respectively. Previous reports on positive effect of PGPR strains on nutrient uptake in faba bean (El-Gizawy and Mehasen, 2009), dill (Hellal et al 2011), Onion (Awad et al 2011), sweet pepper (Zaki et al 2012), strawberry (Ipek et al 2014) and green gram (Kumar et al 2015) were supported our results.

Concerning the triple interaction effects, the inoculated plants with mixture of PGPR strains which fertilized with full dose (90 and $45 \mathrm{~kg} \mathrm{fad} .^{-1}$ ) of nitrogen and phosphorus fertilizers had the highest nitrogen uptake in the shoots (Table 8). Comparable nitrogen uptake in the shoots with the previous combination was observed in the inoculated plants with PGPR strains which treated with full dose of nitrogen and half dose of phosphorus or half dose of nitrogen and full dose of phosphorus. Because of calculation of nitrogen uptake per plant based on shoot dry weight, therefore the prior combinations followed comparable trend as shoot dry weight (Table 6). In the same direction, Barea et al (2002) found that the effectiveness of PGPR increased in soil fertilized by phosphorus in comparison with un-fertilized soil, where the inoculated and $P$ fertilized plants showed higher shoot dry weight, $\mathrm{N}$ and $\mathrm{P}$ uptake by alfalfa plants. Also, the results of Han et al (2006) illustrated that the N, P and $\mathrm{K}$ uptake by pepper and cucumber plants increased by inoculation the plants with PGPR and this effect was due to increasing soil nutrients availability.

It is clear that inoculation plants with PGPR strains significantly increased the shoots nitrogen uptake by $85 \%$ and $55 \%$ compared to uninoculated under zero and half dose of nitrogen, respectively, in the absence phosphorus. These results confirmed that the efficiency of PGPR decreased by increasing nitrogen levels. Also, statistically equal values of nitrogen uptake was found in two different combinations, the first was the inoculated plants with PGPR strains and fertilized with half dose of nitrogen and the second was the plants fertilized with half dose of nitrogen and phosphorus. Regarding to shoots phosphorus uptake, the inoculated plants with PGPR strains and fertilized with half dose of nitrogen and full dose of phosphorus gave non-significant highest phosphorus uptake in the shoots. These results are supported by the results of Adesemoye et al (2009) on tomato and Yasin et al (2012) on cereals who reported that when reduced rates of inorganic fertilizer coupled with microbial inoculants will produce plant growth, yield, and nutrient uptake levels equivalent to those with full rates of the fertilizer. 
Table 6. Effects of triple interaction among nitrogen rate, phosphorus rate and mixture of PGPR on plant growth and fruit yield characters of summer squash cv. Esqndrani

\begin{tabular}{|c|c|c|c|c|c|c|c|}
\hline $\begin{array}{c}\text { Nitrogen } \\
(\mathbf{k g ~ N} \\
\left.\text { fad. }^{-1}\right)\end{array}$ & $\begin{array}{c}\text { Phosphorus } \\
\text { (kg } \mathrm{P}_{2} \mathrm{O}_{5} \\
\left.\text { fad. }{ }^{-1}\right)\end{array}$ & $\begin{array}{c}\text { PGPR } \\
\text { strain } \\
\text { mixture }\end{array}$ & $\begin{array}{c}\text { Shoot fresh } \\
\text { weight } \\
\text { (g/plant) }\end{array}$ & $\begin{array}{l}\text { Shoot dry } \\
\text { weight } \\
\text { (g/plant) }\end{array}$ & $\begin{array}{c}\text { Fruit } \\
\text { No./plant }\end{array}$ & $\begin{array}{c}\text { Fruit } \\
\text { weight } \\
\text { (g/fruit) }\end{array}$ & $\begin{array}{c}\text { Fruit } \\
\text { yield } \\
\text { (t/fad.) }\end{array}$ \\
\hline \multirow{6}{*}{0.0} & \multirow{2}{*}{0.0} & - & $340.75 \mathrm{f}$ & $42.30 \mathrm{f}$ & $2.55 \mathrm{~g}$ & $54.80 \mathrm{~g}$ & 1,96 I \\
\hline & & + & $546.00 \mathrm{e}$ & $63.29 \mathrm{e}$ & $3.02 \mathrm{f}$ & $52.32 \mathrm{gh}$ & $2.25 \mathrm{kl}$ \\
\hline & \multirow{2}{*}{22.5} & - & $652.83 \mathrm{e}$ & $84.06 \mathrm{~d}$ & $3.67 \mathrm{e}$ & $50.02 \mathrm{~h}$ & $2.58 \mathrm{jk}$ \\
\hline & & + & $673.00 \mathrm{e}$ & $86.44 d$ & $3.73 \mathrm{e}$ & $61.55 f$ & $3.23 \mathrm{hi}$ \\
\hline & \multirow{2}{*}{45.0} & - & $621.50 \mathrm{e}$ & $78.54 \mathrm{de}$ & $3.20 \mathrm{f}$ & $62.44 f$ & $2.81 \mathrm{ij}$ \\
\hline & & + & $693.50 \mathrm{e}$ & $85.11 \mathrm{~d}$ & $3.80 \mathrm{e}$ & $63.67 \mathrm{f}$ & $3.39 \mathrm{~h}$ \\
\hline \multirow{6}{*}{45} & \multirow{2}{*}{0.0} & - & $1174.0 \mathrm{~cd}$ & $123.26 \mathrm{c}$ & $5.50 \mathrm{~d}$ & $73.26 \mathrm{de}$ & $5.67 \mathrm{~g}$ \\
\hline & & + & $1413.5 \mathrm{e}$ & $141.74 \mathrm{c}$ & $5.41 \mathrm{~d}$ & 79.22 b & $6.03 \mathrm{fg}$ \\
\hline & \multirow{2}{*}{22.5} & - & $1183.0 \mathrm{~cd}$ & $123.00 \mathrm{c}$ & $6.09 \mathrm{c}$ & $69.14 \mathrm{e}$ & $5.92 \mathrm{~g}$ \\
\hline & & + & $1620.0 \mathrm{~b}$ & $142.26 \mathrm{c}$ & $6.42 \mathrm{bc}$ & $71.23 \mathrm{de}$ & 6.42 ef \\
\hline & \multirow{2}{*}{45.0} & - & $1301.5 \mathrm{~cd}$ & $131.00 \mathrm{c}$ & $6.29 c$ & $74.18 \mathrm{~cd}$ & $6.56 \mathrm{de}$ \\
\hline & & + & $1593.0 \mathrm{~b}$ & $182.00 \mathrm{a}$ & $6.13 c$ & $78.12 \mathrm{bc}$ & $6.73 \mathrm{cde}$ \\
\hline \multirow{6}{*}{90} & \multirow{2}{*}{0.0} & - & $1611.0 \mathrm{~b}$ & $160.81 \mathrm{~b}$ & $6.14 \mathrm{c}$ & $81.15 b$ & $7.01 \mathrm{bcd}$ \\
\hline & & + & $1743.3 \mathrm{ab}$ & $178.11 \mathrm{ab}$ & $6.49 \mathrm{bc}$ & $77.87 \mathrm{bc}$ & $7.10 \mathrm{bc}$ \\
\hline & \multirow{2}{*}{22.5} & - & $1872.5 \mathrm{a}$ & $190.77 \mathrm{a}$ & $6.83 \mathrm{~b}$ & $69.99 \mathrm{de}$ & $6.72 \mathrm{cde}$ \\
\hline & & + & $1819.0 \mathrm{a}$ & $187.97 \mathrm{a}$ & $6.09 c$ & 85.62 a & $7.33 \mathrm{~b}$ \\
\hline & \multirow{2}{*}{45.0} & - & $1859.0 \mathrm{a}$ & $180.35 \mathrm{a}$ & $6.44 \mathrm{bc}$ & 79.97 b & $7.23 \mathrm{bc}$ \\
\hline & & + & $1816.5 \mathrm{a}$ & $181.27 \mathrm{a}$ & $7.30 \mathrm{a}$ & $87.62 \mathrm{a}$ & $9.00 \mathrm{a}$ \\
\hline
\end{tabular}

Notes. Values are the means of three replicates. Values followed by the same letter within a column are not significantly different at the $0.05 \%$ level of probability according to Duncan's multiple-range test.

Table 7. Effects of nitrogen rate, phosphorus rate and mixture of PGPR on macro-elements (NPK) in aerial part and fruits of summer squash cv. Esqndrani

\begin{tabular}{|c|c|c|c|c|c|c|c|}
\hline \multirow{2}{*}{ Main effect } & \multirow{2}{*}{ Levels } & \multicolumn{3}{|c|}{ Shoot mineral uptake (mg/plant) } & \multicolumn{3}{|c|}{ Fruit mineral uptake (mg/plant) } \\
\hline & & $\mathbf{N}$ & $\mathbf{P}$ & $\mathbf{K}$ & $\mathbf{N}$ & $\mathbf{P}$ & $\mathbf{K}$ \\
\hline \multirow{3}{*}{$\begin{array}{l}\text { Nitrogen } \\
\text { (kg N fad. }^{-1} \text { ) }\end{array}$} & 0.0 & $1359.8 \mathrm{c}$ & $740.95 \mathrm{c}$ & 3055.7 c & $452.87 \mathrm{c}$ & $76.69 \mathrm{c}$ & $621.38 c$ \\
\hline & 45 & $3398.2 \mathrm{~b}$ & $1449.2 \mathrm{~b}$ & $5931.9 \mathrm{~b}$ & $1018.9 b$ & $163.04 \mathrm{~b}$ & $1154.6 \mathrm{~b}$ \\
\hline & 90 & $4208.2 \mathrm{a}$ & $1971.6 \mathrm{a}$ & $8006.8 \mathrm{a}$ & $1482.8 \mathrm{a}$ & $391.59 \mathrm{a}$ & $1300.6 \mathrm{a}$ \\
\hline \multirow{3}{*}{ 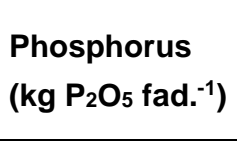 } & 0.0 & $2618.2 \mathrm{~b}$ & $1190.0 \mathrm{~b}$ & $4638.0 \mathrm{c}$ & $840.86 \mathrm{~b}$ & $149.76 \mathrm{c}$ & $872.00 \mathrm{c}$ \\
\hline & 22.5 & $3154.3 \mathrm{a}$ & $1480.6 \mathrm{a}$ & 5596.2 b & $1042.6 \mathrm{a}$ & $220.69 \mathrm{~b}$ & $998.51 \mathrm{~b}$ \\
\hline & 45.0 & $3174.9 \mathrm{a}$ & $1493.6 \mathrm{a}$ & $6734.4 \mathrm{a}$ & $1071.1 \mathrm{a}$ & $260.87 \mathrm{a}$ & $1206.1 \mathrm{a}$ \\
\hline \multirow{2}{*}{$\begin{array}{l}\text { PGPR strain } \\
\text { mixture }\end{array}$} & Uninoculated & $2816.6 \mathrm{~b}$ & $1301.8 b$ & $5333.0 \mathrm{~b}$ & $930.81 \mathrm{~b}$ & $195.86 \mathrm{~b}$ & $941.18 \mathrm{~b}$ \\
\hline & Inoculated & $3139.4 \mathrm{a}$ & $1461.1 \mathrm{a}$ & $5950.1 \mathrm{a}$ & $1038.9 \mathrm{a}$ & $225.01 \mathrm{a}$ & $1109.9 \mathrm{a}$ \\
\hline
\end{tabular}

Notes. Values are the means of three replicates. Values followed by the same letter within a column are not significantly different at the $0.05 \%$ level of probability according to Duncan's multiple-range test. 
The significant highest shoot potassium uptake was found in the inoculated plants with PGPR and fertilized with full dose of nitrogen and phosphorus. In some cases, the inoculated plants with PGPR strains gave the significant higher values of $N, P$ and $\mathrm{K}$ uptake in the shoots in comparison with uninoculated ones, especially in plants non-received $P$ inorganic fertilizer at zero and half dose of nitrogen fertilizer. The improving values were $55 \%$, $31 \%$ and $24 \%$, respectively, in the absence of nitrogen and $85 \%, 48 \%$ and $92 \%$, respectively, at half dose of nitrogen for $\mathrm{N}, \mathrm{P}$ and $\mathrm{K}$ uptake in the shoots (Table 8). Once more, these results supported that the efficiency of PGPR decreased by increasing of nitrogen fertilizer.
The triple interaction of nitrogen and phosphorus fertilizers at high levels (90 and $45 \mathrm{~kg} \mathrm{fad} .^{-1}$ ) as well as treated with PGPR strains gave the highest nitrogen and phosphorus uptake in the fruits, this effect was at significant level for nitrogen. The same combination treatment gave the significant highest fruit $\mathrm{K}$ uptake. The indicated results showed generally that the inoculated plants with PGPR strains significantly enhanced fruits $N, P$ and $\mathrm{K}$ uptake compared to un-inoculated when no phosphorus was applied under each nitrogen level, except potassium uptake under high nitrogen level $\left(90 \mathrm{~kg} \mathrm{fad} .^{-1}\right)$ which significantly unchanged (Table 8).

Table 8. Effects of triple interaction among nitrogen rate, phosphorus rate and mixture of PGPR macroelements (NPK) in aerial part and fruits of summer squash cv. Esqndrani

\begin{tabular}{|c|c|c|c|c|c|c|c|c|}
\hline \multirow{2}{*}{$\begin{array}{c}\text { Nitrogen } \\
(\mathbf{k g ~ N} \\
\left.\text { fad. }^{-1}\right)\end{array}$} & \multirow{2}{*}{$\begin{array}{c}\text { Phosphorus } \\
\left.{\text { (kg } \mathrm{P}_{2} \mathrm{O}_{5}}_{\text {fad. }}^{-1}\right)\end{array}$} & \multirow{2}{*}{$\begin{array}{l}\text { PGPR strain } \\
\text { mixture }\end{array}$} & \multicolumn{3}{|c|}{ Foliage Mineral Content (mg/plant) } & \multicolumn{3}{|c|}{ Fruit Mineral Content (mg/plant) } \\
\hline & & & $\mathbf{N}$ & $\mathbf{P}$ & K & $\mathbf{N}$ & $\mathbf{P}$ & K \\
\hline \multirow{6}{*}{0.0} & \multirow{2}{*}{0.0} & - & $798.83 \mathrm{~h}$ & $458.19 \mathrm{~g}$ & $1565.1 \mathrm{~h}$ & $290.16 \mathrm{~h}$ & $49.22 \mathrm{j}$ & $441.04 \mathrm{i}$ \\
\hline & & + & $1478.7 \mathrm{~g}$ & $681.23 f$ & $3005.5 \mathrm{~g}$ & $454.35 \mathrm{~g}$ & $73.23 \mathrm{i}$ & $560.79 \mathrm{~h}$ \\
\hline & \multirow{2}{*}{22.5} & - & $1457.2 \mathrm{~g}$ & 881.38 def & $3349.2 \mathrm{~g}$ & $465.30 \mathrm{~g}$ & $75.92 \mathrm{i}$ & $607.33 \mathrm{~h}$ \\
\hline & & + & $1576.5 \mathrm{~g}$ & $924.13 \mathrm{de}$ & $3476.2 \mathrm{~g}$ & $501.09 \mathrm{~g}$ & $84.18 \mathrm{i}$ & $637.68 \mathrm{~h}$ \\
\hline & \multirow{2}{*}{45.0} & - & $1365.4 \mathrm{~g}$ & 789.77 ef & $3479.1 \mathrm{~g}$ & $489.85 \mathrm{~g}$ & $88.53 \mathrm{hi}$ & $737.89 \mathrm{~g}$ \\
\hline & & + & $1422.5 \mathrm{~g}$ & 740.85 ef & $3466.0 \mathrm{~g}$ & $516.50 \mathrm{~g}$ & $89.06 \mathrm{hi}$ & $743.56 \mathrm{~g}$ \\
\hline \multirow{6}{*}{45} & \multirow{2}{*}{0.0} & - & $2314.4 f$ & $1031.4 \mathrm{~d}$ & $4539.7 f$ & $718.92 \mathrm{f}$ & $59.53 \mathrm{ij}$ & $586.42 \mathrm{~h}$ \\
\hline & & + & $3588.8 d$ & $1357.0 \mathrm{c}$ & $5672.4 \mathrm{de}$ & $900.49 \mathrm{e}$ & $110.61 \mathrm{gh}$ & $1213.3 \mathrm{e}$ \\
\hline & \multirow{2}{*}{22.5} & - & $3597.4 \mathrm{~d}$ & $1358.4 \mathrm{c}$ & 5355.7 e & $1130.1 \mathrm{~d}$ & $118.41 \mathrm{~g}$ & $923.27 \mathrm{f}$ \\
\hline & & + & $3696.6 \mathrm{~d}$ & $1449.4 \mathrm{c}$ & $5969.7 \mathrm{~d}$ & $1148.7 d$ & $209.14 f$ & I1230.9 e \\
\hline & \multirow{2}{*}{45.0} & - & $2741.0 \mathrm{e}$ & $1396.5 \mathrm{c}$ & $5937.4 \mathrm{~d}$ & $1054.8 d$ & $242.8 \mathrm{e}$ & $1337.5 \mathrm{bcd}$ \\
\hline & & + & $4451.3 \mathrm{ab}$ & $2102.7 \mathrm{a}$ & $8116.7 \mathrm{~b}$ & $1160.6 \mathrm{~d}$ & $237.73 \mathrm{e}$ & $1636.2 \mathrm{a}$ \\
\hline \multirow{6}{*}{90} & \multirow{2}{*}{0.0} & - & $4097.9 \mathrm{c}$ & $1869.5 \mathrm{~b}$ & $6920.7 \mathrm{c}$ & $1270.6 \mathrm{c}$ & $291.43 d$ & $1196.0 \mathrm{e}$ \\
\hline & & + & $4000.4 \mathrm{c}$ & $1997.2 a b$ & 6940.7 c & $1410.7 b$ & $314.54 \mathrm{c}$ & $1234.5 \mathrm{e}$ \\
\hline & \multirow{2}{*}{25.5} & - & $4206.9 \mathrm{bc}$ & $2100.7 \mathrm{a}$ & 8351.7 b & $1483.6 \mathrm{~b}$ & $386.65 \mathrm{~b}$ & 1269.0 de \\
\hline & & + & $4391.3 \mathrm{ab}$ & $2169.3 \mathrm{a}$ & $7074.8 \mathrm{c}$ & $1526.9 \mathrm{~b}$ & $449.84 \mathrm{a}$ & $1322.9 \mathrm{~cd}$ \\
\hline & \multirow{2}{*}{45.0} & - & $4118.8 \mathrm{c}$ & $1830.3 \mathrm{~b}$ & $8480.0 \mathrm{~b}$ & $1474.1 \mathrm{~b}$ & $450.26 \mathrm{a}$ & $1372.1 \mathrm{bc}$ \\
\hline & & + & $4478.7 \mathrm{a}$ & $1898.8 \mathrm{~b}$ & $9517.6 \mathrm{a}$ & $1730.8 \mathrm{a}$ & $456.82 \mathrm{a}$ & 1409.2 b \\
\hline
\end{tabular}

Notes. Values are the means of three replicates. Values followed by the same letter within a column are not significantly different at the $0.05 \%$ level of probability according to Duncan's multiple-range test.

\section{Soil $\mathbf{N}$ and $\mathbf{P}$ availability}

The presented ANOVA data in the Table (4) showed that the main effects of nitrogen, phosphorus fertilizer and PGPR strains as well as their interaction highly significantly $(P<0.001)$ affected the soil nitrogen and phosphorus availability. The indicated results regarding the main effects of nitrogen, phosphorus and application of mixture of PGPR strains showed that the soil nitrogen and phosphorus availability increased significantly by increasing nitrogen rate from 0.0 to $90 \mathrm{~kg}$ fad.- ${ }^{-1}$ 
(more than two fold) at the end of the experiment (Table 9). Regarding the main effect of phosphorus application on mineral soil availability, results showed that nitrogen and phosphorus availability in the soil increased markedly by increasing phosphorus rate. The presented results indicated that the soil inoculated with the mixture of PGPR strains had a significant highest mineral availability ( $\mathrm{N}$ and $\mathrm{P}$ ) compared to un-inoculated soil at the end of the experiment. The increasing percentage was $20.8 \%$ and $17.98 \%$ for nitrogen and phosphorus availability, respectively. One of the most common PGPR activities is to increase the availability of nutrients in the rhizosphere as reported by Gantar and Elhai (1999). From the previous results, the inoculation with PGPR led to an increase of available $P$ in the soil. These increases might be attributed to basic fertilization with superphosphate, solubilization of insoluble inorganic phosphate by the applied rhizobacteria, and the significant reduction in the soil $\mathrm{pH}$. In this regard, Mullen (2005) attributed the ability of rhizobacteria to solubilize mineral phosphates and other nutrients to their capacity to reduce $\mathrm{pH}$ by the excretion of organic acids (e.g. gluconate, citrate, lactate, succinate) and protons during the assimilation of $\mathrm{NH}_{4}{ }^{+}$.

Table 9. Effects of nitrogen rate, phosphorus rate and mixture of PGPR on soil nitrogen and phosphorus available in the soil cultivated with summer squash cv. Esqndrani at the end of experiment

\begin{tabular}{|c|c|c|c|}
\hline Main effect & Levels & $\begin{array}{c}\text { Soil N } \\
\text { available } \\
(\mathrm{mg} / \mathrm{kg})\end{array}$ & $\begin{array}{c}\text { Soil P } \\
\text { available } \\
(\mathrm{mg} / \mathrm{kg})\end{array}$ \\
\hline \multirow{3}{*}{ 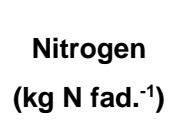 } & 0.0 & $19.41 \mathrm{c}$ & $15.36 \mathrm{c}$ \\
\hline & 45 & $35.45 \mathrm{~b}$ & $18.29 b$ \\
\hline & 90 & $42.39 \mathrm{a}$ & $21.28 \mathrm{a}$ \\
\hline \multirow{3}{*}{$\begin{array}{l}\text { Phosphorus } \\
{\text { (kg } \mathrm{P}_{2} \mathrm{O}_{5}}^{\left.\text {fad } .^{-1}\right)}\end{array}$} & 0.0 & $24.85 \mathrm{c}$ & $15.06 \mathrm{c}$ \\
\hline & 22.5 & $33.26 b$ & $18.85 b$ \\
\hline & 45.0 & $39.14 \mathrm{a}$ & $21.02 \mathrm{a}$ \\
\hline \multirow{2}{*}{$\begin{array}{c}\text { PGPR strain } \\
\text { mixture }\end{array}$} & Uninoculated & 29.36 b & $16.80 \mathrm{~b}$ \\
\hline & Inoculated & $35.47 \mathrm{a}$ & 19.82 a \\
\hline
\end{tabular}

Notes. Values are the means of three replicates. Values followed by the same letter within a column are not significantly different at the $0.05 \%$ level of probability according to Duncan's multiplerange test.

Concerning the triple interaction effects on nitrogen and phosphorus availability in the soil at the end of experiment, the indicated results showed that the highest available nitrogen and phosphorus in the soil were corresponding with the combination treatment containing high nitrogen, high phosphorus and inoculation with PGPR strains (Table 10). This effect was at significant level regarding to nitrogen availability. The inoculated plants with PGPR strains and fertilized with full dose of nitrogen and half dose of phosphorus gave the significant highest soil phosphorus availability. Generally, the plants inoculated with PGPR strains gave the significant highest values of nitrogen and phosphorus availability under each level of nitrogen or phosphorus (Table 10). It is well reported that the inoculation with PGPR strains enhanced soil mineral availability (Richardson et al 2009; Basak and Biswas, 2010; Wu et al 2012). Our indicated results supported by the findings of Han et al (2006) on pepper and cucumber who found that the availability of $P$ increased by inoculation with PGPR.

Table 10. Triple interaction effects among nitrogen rate, phosphorus rate and mixture of PGPR on soil nitrogen and phosphorus available in the soil cultivated with summer squash cv. Esqndrani at the end of experiment.

\begin{tabular}{|c|c|c|c|c|}
\hline $\begin{array}{c}\text { Nitrogen } \\
(\mathbf{k g ~ N} \\
\left.\text { fad. }^{-1}\right)\end{array}$ & $\begin{array}{l}\text { Phosphorus } \\
{\text { (kg } \mathrm{P}_{2} \mathrm{O}_{5}} \\
\left.\text { fad. }{ }^{-1}\right)\end{array}$ & $\begin{array}{c}\text { PGPR } \\
\text { strain } \\
\text { mixture }\end{array}$ & $\begin{array}{c}\text { Soil N } \\
\text { available } \\
(\mathrm{mg} / \mathrm{kg})\end{array}$ & $\begin{array}{c}\text { Soil P } \\
\text { available } \\
(\mathrm{mg} / \mathrm{kg})\end{array}$ \\
\hline \multirow{6}{*}{0.0} & \multirow{2}{*}{0.0} & - & 14.931 & $9.39 \mathrm{i}$ \\
\hline & & + & $19.37 \mathrm{j}$ & $14.36 \mathrm{~h}$ \\
\hline & \multirow{2}{*}{22.5} & - & $17.27 \mathrm{k}$ & $15.30 \mathrm{gh}$ \\
\hline & & + & $19.60 \mathrm{j}$ & $16.18 \mathrm{~g}$ \\
\hline & \multirow{2}{*}{45.0} & - & $22.40 \mathrm{hi}$ & $18.13 \mathrm{f}$ \\
\hline & & + & $22.87 \mathrm{hi}$ & 18.81 ef \\
\hline \multirow{6}{*}{45} & \multirow{2}{*}{0.0} & - & 21.23. i & $14.75 \mathrm{~h}$ \\
\hline & & + & $24.73 \mathrm{~g}$ & $17.77 \mathrm{fg}$ \\
\hline & \multirow{2}{*}{22.5} & - & $31.50 \mathrm{f}$ & $16.14 \mathrm{~g}$ \\
\hline & & + & $44.83 \mathrm{c}$ & $20.47 \mathrm{~cd}$ \\
\hline & \multirow{2}{*}{45.0} & - & $44.00 \mathrm{~d}$ & 19.39 e \\
\hline & & + & $46.40 \mathrm{c}$ & $21.22 \mathrm{c}$ \\
\hline \multirow{6}{*}{90} & \multirow{2}{*}{0.0} & - & $23.1 \mathrm{~h}$ & $15.37 \mathrm{gh}$ \\
\hline & & + & $45.73 \mathrm{c}$ & 18.73 ef \\
\hline & \multirow{2}{*}{22.5} & - & $41.07 \mathrm{e}$ & 19.69 de \\
\hline & & + & $45.30 \mathrm{~cd}$ & $25.34 \mathrm{a}$ \\
\hline & \multirow{2}{*}{45.0} & - & $48.77 \mathrm{~b}$ & $23.05 b$ \\
\hline & & + & $50.40 \mathrm{a}$ & $25.50 \mathrm{a}$ \\
\hline
\end{tabular}

Notes. Values are the means of three replicates. Values followed by the same letter within a column are not significantly different at the $0.05 \%$ level of probability according to Duncan's multiplerange test. 


\section{CONCLUSION}

Results of the first experiment indicated that inoculation with PGPR strains improved fruit yield characters. The double inoculations were the best inoculation method than single and triple inoculations. The results of the second experiment showed that the efficiency of $\mathrm{N}$ and $\mathrm{P}$ fertilization increased by inoculation with PGPR mixture (Azospirillum brasilense AC1 and Serratia marcescens BM1). PGPR mixture significantly increased the efficiency of applied chemical fertilizers by increasing nutrient availability and uptake for plant. Fruit yield of plants received full doses of $\mathrm{N}$ and $\mathrm{P}$ were significantly superior when plants were inoculated with PGPR strains. Under no and half dose of nitrogen fertilizer, it could be possible to substitute chemical $P$ fertilizer by inoculation with mixture of PGPR strains. From the results of present study, it could be concluded that the inoculation with PGPR can enhance plant uptake of nutrients and thereby increase the use efficiency of applied chemical fertilizers.

\section{REFERANCES}

Abd El-Azeem, S.A.M., Mehana, T.A., Shabayek, A.A. 2007. Some plant-growth-promoting traits of rhizobacteria isolated from Suez Canal region, Egypt. African Crop Science Conference Proceedings 8: 1517-1525.

Abd El-Azeem, S.A.M., Elwan, M.W.M., Sung, J.K. and Ok, Y.S. 2012. Alleviation of Salt Stress in Eggplant (Solanum melongena L.) by Plant-Growth-Promoting Rhizobacteria. Communications in Soil Science and Plant Analysis. 43: 1303-1315.

Abdel-Aziez, Samah, M., Eweda, W.E., Girgis, M.G.Z. and Abdel Ghany, B.F. 2014. Improving the productivity and quality of black cumin (Nigella sativa) by using Azotobacter as $\mathrm{N}_{2}$ biofertilizer. Ann. Agric. Sci., 59(1): 95-108.

Abou-Aly, H.E., Mady, M.A. and Moussa, S.A.M. 2006. Interaction effect between phosphate dissolving microorganisms and boron on squash (cucurbita pepo I.) growth, endogenous phytohormones and fruit yield. Biol Chem Environ Sci, 1(4): 751-774.

Adesemoye, A.O. and Kloepper, J.W. 2009. Plant-microbes interactions in enhanced fertilizer-use efficiency. Appl. Microbiol. Biotechnol. 85, 1-12.

Adesemoye, A.O., Torbert, H.A. and Kloepper, J.W. 2009. Plant growth promoting rhizobacte- ria allow reduced application rates of chemical fertilizers. Microb Ecol., 58: 921-929.

Ahemad, M. and Kibret, M. 2014. Mechanisms and applications of plant growth promoting rhizobacteria: Current perspective. J. King Saud Univ. Sci. 26(1): 1-20.

Awad, N. M., Abd El-Kader, A.A., Attia, M. and Alva, A.K. 2011. Effects of nitrogen fertilization and soil inoculation of sulfur-oxidizing or nitrogen-fixing bacteria on onion plant growth and yield. International J. Agron., 2011: 1-6.

Barea, J.M., Toro, M., Orozco, M. O., Campos, E. and Azcón, R. 2002. The application of isotopic (32P and $15 \mathrm{~N}$ ) dilution techniques to evaluate the interactive effect of phosphatesolubilizing rhizobacteria, mycorhizal fungi and Rhizobium to improve the agronomic efficiency of rock phosphate for legume crops. Nutr Cycling Agroecosys 63: 35-42.

Basak, B.B. and Biswas, D.R. 2010. Coinoculation of potassium solubilizing and nitrogen fixing bacteria on solubilization of waste mica and their effect on growth promotion and nutrient acquisition by a forage crop. Biol. Fertil. Soils 46: 641-648.

Bremner, J.M. 1996. Nitrogen-Total. In: Sparks D.L., Page A.L., Helmke P.A., Loeppert R.H., Soltanpour P.N., Tabatabai M.A., Johnston C.T., Sumner M.E., editors. Methods of Soil Analysis, Part 3, Chemical Methods. SSSA Inc. and ASA Inc.; Madison, WI, USA. pp. 10851122.

Dinesh, R., Anandaraj, M., Kumar, A., Srinivasan, V., Bini, Y. K., Subila, K. P., Aravind, R. and Hamza, S. 2013. Effects of plant growthpromoting rhizobacteria and npk fertilizers on biochemical and microbial properties of soils under ginger (Zingiber officinale) Cultivation. Agric. Res. 2(4): 346-353.

Ekin Z. 2010. Performance of phosphate solubilizing bacteria for improving growth and yield of sunflower (Helianthus annuus L.) in the presence of phosphorus fertilizer. African J. Biotech., 9: 3794-3800.

El-Gizawy, N.K.B. and Mehasen, S.A.S. 2009. Response of Faba Bean to Bio, Mineral Phosphorus Fertilizers and Foliar Application with Zinc. World Appl. Sci. J., 6(10): 1359-1365.

Elwan M.W.M. and El-Shatoury, R.S.A. 2012. Salicylic acid positively affected plant growth, photosynthetic leaf pigments and fruit yield of summer squash (Cucurbita pepo L.) grown under different N-levels. Mansoura J. Plant Production 3(7): 2123-2138. 
FAO., 2012.

http://faostat.fao.org/site/567/default.aspx\#anco r. Rome, Italy: FAO.

Felici, C., Vettori, L., Giraldi, E., Forino, L.M.C., Toffanin, A., Tagliasacchi, A.M. and Nuti, M. 2008. Single and co-inoculation of Bacillus subtilis and Azospirillum brasilense on Lycopersicon esculentum: Effects on plant growth and rizosphere microbial community. Appl. Soil Eco., 40: 260-270.

Gantar, M. and Elhai, J. 1999. Colonization of Wheat Para nodules by the $\mathrm{N}_{2}$ - fixing Cyanobacterium Nostoc sp. strain 2S9B. New Phytol. 141: 373-379.

Gee, G.W. and Bauder, J.W. 1986. Particle-size Analysis. In: Klute A., Campbell G.S., Nielsen D.R., Jackson R.D., Mortland M.M., editors. Methods of Soil Analysis, Part 1, Physical and Mineralogical Methods. 2nd ed. SSSA Inc. and ASA Inc.; Madison, WI, USA. pp. 383-412.

Goswami, D., Parmar, S., Vaghela, H., Dhandhukia, P. and Thakker, J.N. 2015. Describing Paenibacillus mucilaginosus strain N3 as an efficient plant growth promoting rhizobacteria (PGPR). Cogent Food \& Agric., 1: 1-13. http://dx.doi.org/10.1080/23311932.2014.10007 $\underline{14}$

Guang-Can, T. Shu-Jun, T., Miao-Ying, C. and Guang-Hui, X. 2008. Phosphate-solubilizing and -mineralizing abilities of bacteria isolated from soils. Pedosphere 18(4): 515-523.

Han, H.S. and Supanjani, Lee, K.D. 2006. Effect of co-inoculation with phosphate and potassium solubilizing bacteria on mineral uptake and growth of pepper and cucumber. Plant Soil Environ. 52(3): 130-136.

Haque, M.A. and Khan, M.K. 2012. Effects of Phosphatic Biofertilizer with Inorganic and Organic Sources of Phosphorus on Growth and Yield of Lentil. J. Environ. Sci. \& Natural Resources, 5(2): 225-230.

Hellal, F.A., Mahfouz, F.A. and Hassan, F.A.S. 2011. Partial substitution of mineral nitrogen fertilizer by bio-fertilizer on (Anethum graveolens L.) plant. Agric. Biol. J.N. Am., 2(4), 652660.

Hontzeas, N., Richardson, A.O., Belimov, A.A., Safronova, V.I., Abu-Omar, M.M. and Glick, B.R. 2005. Evidence for horizontal gene transfer (HGT) of ACC deaminase genes. Appl Environ Microbiol. 71: 7556-7558.

Ipek, M., Pirlak, L., Esitken, A., Dönmez, M.F., Turan, M. and Sahin, F. 2014. Plant growthpromoting rhizobacteria (PGPR) increase yield, growth and nutrition of strawberry under highcalcareous soil conditions. J. Plant Nutr. 37: 990-1001.

Jackson, M.L. 1973. Soil chemical analysis. New Delhi, India: Prentice Hall of India Pvt. Ltd.

Jasso-Chaverria, C., Hochmuth, G.J., Hochmuth, R.C. and Sargent, S.A. 2005. Fruit yield, size, and color responses of two greenhouse cucumber types to nitrogen fertilization in perlite soilless culture. HortTechno., 15,565-571.

Kim, K.Y., Deka Boruah, H.P., Kim, C.W., Shagol, C.C. and Sa, T.M. 2010. Isolation and evaluation of inoculation effect of Azospirillum sp. on growth, colonization and nutrient uptake of crops under greenhouse condition. 19th World Congress of Soil Science, Soil Solutions for a Changing World, 1-6 August, Brisbane, Australia, pp. 60-63.

Kloepper, J.W. and Schroth, M.N. 1978. Plant growth-promoting rhizobacteria on radishes. In: Proceedings of the 4th International Conference on Plant Pathogenic Bacteria, vol. 2. Station de Pathologie Veégé tale et de Phytobact riologié, INRA, Angers, France, pp. 879-882.

Kumar, G.P., Desai, S., Amalraj, E.L.D. and Pinisetty, S. 2015. Impact of seed bacterization with PGPR on growth and nutrient uptake in different cultivable varieties of green gram. Asian J. Agric. Res., 9 (3): 113-122.

Kumar, K.S.N., Sowmyamala, B.V., Kumar, P.G. S., Vasudev, P.N., Kumar, R.V. and Nagaraj, H.T. 2012. Effect of plant growth promoting rhizobacteria (PGPR) on growth and yield of bitter gourd. International J. Appl. Biol. Pharmaceutical technol., 3(1): 1-7.

Kuo, S. 1996. Phosphorus. In: Methods of Soil Analysis, part 3 Chemical Methods. Sparks et al. (Eds.), Soil Science Society of America, Madison, WI, USA, pp. 869-919.

Li, W., Li, L., Sun, J., Zhang, E. and Christie, P. 2003. Effects of Nitrogen and Phosphorus Fertilizers and Intercropping on Uptake of Nitrogen and Phosphorus by Wheat, Maize, and Faba Bean. J. Plant Nutr., 26 (3): 629-642.

Lucas García, J.A., Probanza, A., Ramos, B., Palomino, M.R. and Mañero, F.J.G. 2004. Effect of inoculation of Bacillus licheniformis on tomato and pepper. Agronomie 24: 169-176.

Malboobi, M.A., Owlia, P., Behbahani, M., Sarokhani, E., Moradi, S.,Yakhchali, B., Deljou, A. and Heravi, K.M. 2009. Solubilization of organic and inorganic phosphates by three highly 
efficient soil bacterial isolates. World J. Microbiol Biotechnol 25: 1471-1477.

Mehta, P., Walia, A., Kulshrestha, S., Chauhan, A. and Shirkot, C.K. 2014. Efficiency of plant growth-promoting $\mathrm{P}$-solubilizing Bacillus circulans CB7 for enhancement of tomato growth under net house conditions. J. Basic Microbiol. 53: 1-12.

Mena-Violante, H.G. and Olalde-Portugal, V. 2007. Alteration of tomato fruit by root inoculation with plant growth-promoting rhizobacteria (PGPR): Bacillus subtilis BEB-13bs. Sci. Hortic., 113(1, 5): 103-106.

Mohammad, M.J. 2004. Squash yield, nutrient content and soil fertility parameters in response to methods of fertilizer application and rates of nitrogen fertigation. Nutr. Cycling in Agroecosystems 68: 99-108.

Mohammad, M.J., Hammour, A. and Ferdows, A.E. 2004. Phosphorus fertigation and preplant conventional soil application of drip irrigated summer squash. J. Agron. 3(3): 162-169.

Moinuddin, Dar, T.A., Hussain, S.M., Khan, M. A., Hashmi, N., Idrees, M., Naeem, M. and Ali, A., 2014. Use of $N$ and $P$ biofertilizers together with phosphorus fertilizer Improves growth and physiological attributes of chickpea. Glob. J. Agric. Agric. Sci., 2(3):168-174.

Mullen, M.D. 2005. Phosphorus in soils: biological interactions. In: Encyclopedia of soils in the Environment. D. Hillel; C. Rosenzweig; D. Powlson; K. Scow; M. Singer and D. Sparks (eds). Academic Press, Elsevier, Ltd, Oxford, pp. 210-248.

Ogut, M., Akdag, C. and Sakin, O.D.M.A. 2005. Single and double inoculation with Azospirillum/ Trichoderma: the effects on dry bean and wheat. Biol. Fertil. Soils 41: 262-72.

Persello-Cartieaux, F., Nussaume, L. and Robaglia, C. 2003. Tales from the underground: Molecular plant-rhizobacteria interactions. Plant, Cell and Environment 26:189-199.

Richardson, A.E., Barea, J.M., McNeill, A.M. and Combaret, C.P. 2009. Acquisition of phosphorus and nitrogen in the rhizosphere and plant growth promotion by microorganisms. Plant Soil 321: 305-339.

Rodriguez, H., Gonzalez, T., Goireand, I. and Bashan, Y. 2004. Gluconic acid production and phosphate solubilization by the plant growthpromoting bacterium Azospirillum spp. Naturewissenschaften, 91: 552-555.

Saber, Z., Pirdashti, H., Esmaeili, M., Abbasian, A. and Heidarzadeh, A. 2012. Response of wheat growth parameters to co-inoculation of plant growth promoting rhizobacteria (PGPR) and different levels of inorganic nitrogen and phosphorus. World Appl. Sci. J., 16(2): 213219.

Shaharoona, B., Naveed, M., Arshad, M. and Zahir, Z.A. 2008. Fertilizer-dependent efficiency of Pseudomonads for improving growth, yield, and nutrient use efficiency of wheat (Triticum aestivum L.). Appl. Microbiol. Biotechnol. 79: 147-155.

Shalaby, M.A.F. and Ahmed, M.A. 1993. Yield response of faba bean to $\mathrm{GA}_{3}$ time of application in relation to phosphorus fertilization. Ann. Agric. Sci. Moshtohor, 31: 1989-1998.

Sharma, T. and Rai, N. 2015. Isolation of Plant Hormone (Indole-3-Acetic Acid) Producing Rhizobacteria and Study on their Effects on Tomato (Lycopersicum esculentum) Seedling. International J. PharmTech Res., 7(1): 99-107.

Shehata, Sawsan, F. and El-Borollosy, A.M. 2008. Induction of resistance against zucchini yellow mosaic Potyvirus and growth enhancement of squash plants using some plant growth-promoting rhizobacteria. Australian Journal of Basic and Applied Sciences, 2(2): 174-182.

Shrivastava, U.P. and Kumar, A. 2011. Biochemical characterization of siderophore producing plant growth promoting rhizobacteria of rice rhizosphere. Nep. J. Integrated Sci. 1: 31-37.

Somers, E., Ptacek, D., Gysegom, P., Srinivasan, M. and Vanderleyden, J. 2005. Azospirillum brasilense Produces the Auxin-Like Phenylacetic Acid by Using the Key Enzyme for Indole-3-Acetic Acid Biosynthesis. Appl \& Environ. Microbiol., 71: 1803-1810.

Sparks, D.L., Page, A.L., Helmke, P.A., Loeppert, R.H., Soltanpour, P.N., Tabatabai, M.A., Johnston, C.T. and Sumner, M.E. 1996. Methods of soil analysis. Madison, Wisc.: ASA and SSSA.

Starr, M.P. 1981. The genus Xanthomonas, in: The prokaryotes (M.P. et al eds) pp. 742-763, springer-verlag, Berlin.

Statsoft, Inc. 2001. STATISTICA for Windows, version 6. http://www.Statsoft.com. Tulsa, Okla.: Statsoft.

Steenhoudt, O. and Vanderleyden, J. 2000. Azospirillum, a free-living nitrogen-fixing bacterium closely associated with grasses: genetic, biochemical and ecological aspects. FEMS Microbiol Rev. 24(4): 487-506. 
Tailor, A.J. and Joshi. P.H. 2014. Harnessing plant growth promoting rhizobacteria beyond nature: a review. J. Plant Nutr., 37: 15341571.

Tahir, M. and Sarwar, M.A. 2013. Plant Growth Promoting Rhizobacteria (PGPR): A Budding Complement of Synthetic Fertilizers for Improving Crop Production. Pak. J. Life Soc. Sci., 11(1): 1-7.

Tanwar, A., Aggarwal, A. and Parkash, V. 2014. Effect of bioinoculants and superphosphate fertilizer on the growth and yield of broccoli (Brassica oleracea L. var. italica Plenck). New Zealand J. Crop and Hortic. Sci., 42(4): 288-302.

Tariq, M., Ali, Q., Khan, A., Khan, G. A., Rashid, B., Rahi, M.S., Ali, A., Nasir, I.A. and Husnain, T. 2014. Yield potential study of Capsicum annuum L. under the application of PGPR. Advancements in Life Sci., 1(4): 202207.

Tsavkelova, E.A., Klimova, S.Y., Cherdyntseva, T.A. and Netrusov, A.I. 2006. Microbial producers of plant growth stimulators and their practical use: a review. Appl. Biochem. \& Microbiol., 42: 117-126.

Vitousek, P.M., Aber, J.D., Howarth, R.W., Likens, G.E. and Matson, P.A. 1997. Human alteration of the global nitrogen cycle: sources and consequences. Ecolog. Appl. 7(3): 737750.

Wu, F., Wan, J.H.C., Wu, S. and Wong, M. 2012. Effects of earthworms and plant growthpromoting rhizobacteria (PGPR) on availability of nitrogen, phosphorus, and potassium in soil. J. Plant Nutr. Soil Sci. 175: 423-433.

Yang J., Kloepper J. and Ryu, C. 2009. Rhizosphere bacteria help plants tolerate abiotic stress. Trends in Plant Sci. 14: 1-4.

Yasin, M., Ahemad, A., Mussarat, W. and Tanveer, A. 2012. Bio-fertilizers, substitution of synthetic fertilizers in cereals for leveraging agriculture. Crop \& environ., 3(1-2): 62-66.

Yildirim, E., Karlidag, H., Turan, M. and Dursun, A. 2011. Growth, nutrient uptake, and yield promotion of broccoli by plant growth promoting rhizobacteria with manure. Hortscience 46(6): 932-936.

Yousefi, A.A., Khavazi, K., Moezi, A.A., Rejali, F. and Nadian, H.A. 2011. Phosphate Solubilizing Bacteria and Arbuscular Mycorrhizal Fungi Impacts on Inorganic Phosphorus Fractions and Wheat Growth. World Appl. Sci. J., 15(9): 1310-1318.

Zabihi, H.R., Savaghebi, G.R., Khavazi, K., Ganjali, A. and Miransari, M. 2011. Pseudomonas bacteria and phosphorous fertilization, affecting wheat (Triticum aestivum L.) yield and $\mathrm{P}$ uptake under greenhouse and field conditions. Acta Physiol Plant 33: 145-152.

Zafar, M., Abbasi, M.K., Rahim, N., Khaliq, A., Shaheen, A., Jamil, M. and Shahid, M. 2011. Influence of integrated phosphorus supply and plant growth promoting rhizobacteria on growth, nodulation, yield and nutrient uptake in Phaseolus vulgaris African J. Biotechnol., 10(74): 16793-16807.

Zaki, M.F., Fawzy, Z.F., Ahmed, A.A. and Tantawy, A.S. 2012. Application of phosphate dissolving bacteria for improving growth and productivity of two sweet pepper (Capsicum annuum I.) Cultivars under newly reclaimed soil. Australian J. Basic \& Appl. Sci., 6(3), 826-839.

Zhang S., White, T.L., Martinez, M.C., Mclnroy, J. A., Kloepper, J.W. and Klassen, W. 2010. Evaluation of plant growth-promoting rhizobacteria for control of Phytophthora blight on squash under greenhouse conditions. Biological Control 53: 129-135. 